\title{
Impacts of genetically engineered crops on pesticide use in the U.S. - the first sixteen years
}

\author{
Charles M Benbrook
}

\begin{abstract}
Background: Genetically engineered, herbicide-resistant and insect-resistant crops have been remarkable commercial successes in the United States. Few independent studies have calculated their impacts on pesticide use per hectare or overall pesticide use, or taken into account the impact of rapidly spreading glyphosate-resistant weeds. A model was developed to quantify by crop and year the impacts of six major transgenic pest-management traits on pesticide use in the U.S. over the 16-year period, 1996-2011: herbicide-resistant corn, soybeans, and cotton; Bacillus thuringiensis (Bt) corn targeting the European corn borer; Bt corn for corn rootworms; and Bt cotton for Lepidopteron insects.

Results: Herbicide-resistant crop technology has led to a 239 million kilogram (527 million pound) increase in herbicide use in the United States between 1996 and 2011, while Bt crops have reduced insecticide applications by 56 million kilograms (123 million pounds). Overall, pesticide use increased by an estimated 183 million kgs (404 million pounds), or about 7\%.

Conclusions: Contrary to often-repeated claims that today's genetically-engineered crops have, and are reducing pesticide use, the spread of glyphosate-resistant weeds in herbicide-resistant weed management systems has brought about substantial increases in the number and volume of herbicides applied. If new genetically engineered forms of corn and soybeans tolerant of 2,4-D are approved, the volume of 2,4-D sprayed could drive herbicide usage upward by another approximate 50\%. The magnitude of increases in herbicide use on herbicide-resistant hectares has dwarfed the reduction in insecticide use on Bt crops over the past 16 years, and will continue to do so for the foreseeable future.
\end{abstract}

Keywords: Herbicide-resistant crops, Herbicide-tolerant soybeans, Glyphosate, 2,4-D, Bt crops, Genetically engineered corn, Roundup Ready crops, Biotechnology and pesticide use, Glyphosate resistant weeds

\section{Background}

Public debate over genetically engineered (GE) crops is intensifying in the United States (U.S.), driven by new science on the possible adverse health impacts associated with herbicide-resistant (HR) crop pesticide use, and the rapid spread of glyphosate-resistant weeds. Still, many experts and organizations assert that GE crops have reduced, and continue to reduce herbicide, insecticide, and overall pesticide use. Fortunately, high quality and publically accessible U.S. Department of Agriculture (USDA) pesticide use data are available and can be used to track changes in pesticide use on crops containing GE traits. Moreover, the impacts of these traits on U.S.

Correspondence: cbenbrook@wsu.edu

Centre for Sustaining Agriculture and Natural Resources, Washington State University, Hulbert 421, PO Box 646242, Pullman, WA 99164-6242, USA pesticide use trends are substantial and obvious, especially in recent years as a result of the growing number and geographical spread of glyphosate-resistant (GR) weeds.

Stable reductions in insecticide use in Bt-transgenic corn are also now in jeopardy as a result of the emergence of corn rootworm (CRW) populations resistant to the Cry $3 \mathrm{Bb} 1$ toxins expressed in several corn hybrids [1,2]. To combat this ominous development, some seed and pesticide companies are recommending a return to use of corn soil insecticides as a resistance management tool. There is a degree of irony in such recommendations, given that the purpose of Cry $3 \mathrm{Bb} 1$ corn was to eliminate the need for corn soil insecticides.

The emergence of herbicide-resistant genetically engineered crops in 1996 made it possible for farmers to use a broad-spectrum herbicide, glyphosate, in ways that were 
previously impossible. From 1996 through 2011, 0.55 billion hectares of HR corn (Zea mays), soybeans (Glycine max), and cotton (Gossypium hirsutum) were grown in the U.S. [Additional file 1: Table S7]. In 2011, an estimated $94 \%$ of the soybean area planted, $72 \%$ of corn, and $96 \%$ of cotton were planted to $\mathrm{HR}$ varieties, respectively, while about $65 \%$ of corn and $75 \%$ of cotton hectares in the U.S. were planted to $B t$ varieties [Additional file 1: Table S6].

Glyphosate-resistant, Roundup Ready (RR) crops now comprise the overwhelming majority of HR crops. RR crops were rapidly adopted because they provided farmers a simple, flexible, and forgiving weed management system, especially compared to systems reliant on the low-dose, persistent herbicide chemistries on the market in the late 1990s, such as imazethapyr (43\% soybean hectares treated in 1996) and chlorimuron-ethyl (14\% treated). From 1996 through 2008, HR crops resistant to herbicides other than glyphosate either disappeared from the market (e.g. bromoxynil HR cotton), or have been planted on relatively few hectares (e.g. glufosinate HR, LibertyLink cotton and corn).

Net reductions in pesticide use, encompassing changes in both herbicide and insecticide kilograms/pounds applied, are among the purported claims of GE crops [3-5]. Analysts assessing the impacts of $B t$ crops on insecticide use report reductions, or displacement, in the range of $25 \%$ to $50 \%$ per hectare [6]. A more recent study reports a $24 \%$ reduction [5]. On GE and non-GE corn since 1996, the volume of insecticides applied has declined, because of the pesticide industry-wide trend toward more biologically active insecticides applied at incrementally lower application rates.

The corn rootworm (CRW) has been the target of the majority of corn insecticide applications the last several decades. The average corn insecticide application rate in 1996 was about 0.76 kilograms of active ingredient per hectare (kgs/ha) (0.7 pounds/acre) and is less than $0.2 \mathrm{kgs} /$ ha today (0.18 pounds a.i./acre) [Additional file 1: Table S12]. The two contemporary corn soil insecticide market leaders - tebupirimiphos and tefluthrin - are applied at average rates around $0.13 \mathrm{kgs} / \mathrm{ha}$ ( 0.12 pounds/acre). In 1996, the market leaders were chlorpyrifos and terbufos, insecticides applied at rates above $1.12 \mathrm{kgs} / \mathrm{ha}$ (1.0 pounds/ acre) [Additional file 1: Table S12]. Obviously, planting Bt corn in 2011 reduced insecticide use less significantly compared to land planted to $B t$ corn in the late 1990s.

Few comprehensive estimates have been made of the impacts of HR crops on herbicide use. The USDA has not issued a new estimate in well over a decade; the USDA's Economic Research Service (ERS) reported an 3.7 million $\mathrm{kg}$ (8.2 million pound) decrease in pesticide use in 1998 as a result of GE corn, soybeans, and cotton [7], an estimate that is comparable to the present study's estimate of a 4.4 million $\mathrm{kg}$ (9.6 million pound) reduction [Additional file 1: Table S15]. A series of unpublished simulation studies have been carried out by the National Center for Food and Agriculture Policy (NCFAP). In a report covering crop year 2005, NCFAP projected that HR corn, soybean, and cotton reduced total herbicide use by 25.6 million kgs, compared to hectares planted to non-HR varieties [6]. Sankula's herbicide use estimates are based on observations of mostly university experts regarding "typical" herbicide use rates on farms planting HR versus non-HR varieties. The rates incorporated in Sankula's estimates often differ from those published for the same year by USDA's National Agricultural Statistics Service (NASS) [8]. NASS reported that an average 1.5 applications of glyphosate were made on HR soybeans in 2005, while Sankula assumes only 1.18 applications. Sankula's estimate of total herbicide use on RR soybeans in 2005, $1.15 \mathrm{kgs} / \mathrm{ha}$ (1.03 pounds/acre), is less than the NASS figure for glyphosate alone, $1.23 \mathrm{kgs} / \mathrm{ha}$ (1.1 pounds/acre). If true, Sankula's data suggests that essentially no other herbicides were applied to RR soybeans in 2005, when in fact the average soybean hectare in 2002 was treated with 1.66 herbicides according to NASS data.

This paper quantifies the impacts of GE crops on the kilograms of pesticides applied per hectare and across all GE hectares, drawing upon publicly accessible USDA data. The pesticide use impacts of the six major, commercial GE pest-management traits are modeled and then aggregated over the 16 years since commercial introduction. While most of the pesticide use data incorporated in the model were originally reported by U.S. government agencies in pounds of active ingredient, and/or pounds of a.i./ acre, results are reported herein in SI units (kilograms of active ingredient and $\mathrm{kg} / \mathrm{ha}$ ). Some key results are also reported in pounds/acre. Convert kilograms to pounds by multiplying by 2.205 , and pounds to $\mathrm{kgs}$ by multiplying by 0.454 . To convert from $\mathrm{kg} / \mathrm{ha}$ to pounds/acre, multiply by 0.893 ; to convert from pounds/acre to $\mathrm{kg} / \mathrm{ha}$, multiply by 1.12 .

\section{Results and discussion}

Farmers planted 0.55 billion hectares ( 1.37 billion acres) of HR corn, soybeans, and cotton from 1996 through 2011, with HR soybeans accounting for $60 \%$ of these hectares [Additional file 1: Table S7]. In terms of overall herbicide use per hectare based on NASS data, substantial increases have occurred from 1996 through 2011. In soybeans, USDA reported herbicide applications totaling $1.3 \mathrm{kgs} / \mathrm{ha}$ (1.17 pounds/acre) in 1996 , and $1.6 \mathrm{kgs} / \mathrm{ha}$ (1.42 pounds/ acre) in 2006, the last year soybeans were surveyed by USDA. In cotton, herbicide use has risen from $2.1 \mathrm{kgs} / \mathrm{ha}$ (1.88 pounds/acre) in 1996 to $3.0 \mathrm{kgs} / \mathrm{ha}$ (2.69 pounds/ acre) in 2010, the year of the most recent USDA survey. In the case of corn, herbicide use has fallen marginally from $3.0 \mathrm{kgs} / \mathrm{ha}$ (2.66 pounds/acre) in 1996 to $2.5 \mathrm{kgs} / \mathrm{ha}$ 
(2.26 pounds/acre) in 2010, largely as a result of lessened reliance on older, high-rate herbicides.

Compared to herbicide use rates per hectare on non-HR hectares, HR crops increased herbicide use in the U.S. by an estimated 239 million kgs (527 million pounds) in the 1996-2011 period, with HR soybeans accounting for 70\% of the total increase across the three HR crops. Rising reliance on glyphosate accounted for most of this increase.

In light of its generally favorable environmental and toxicological properties, especially compared to some of the herbicides displaced by glyphosate, the dramatic increase in glyphosate use has likely not markedly increased human health risks. Because glyphosate cannot be sprayed on most actively growing, non-GE plants, residues of glyphosate in food have been rare, at least until the expansion 2006 in the number of late-season glyphosate applications on wheat and barley as a harvest aid and/ or to control escaped weeds. Presumably as a result of such uses, $5.6 \%$ of 107 bread samples tested in 2010 by the U.K. Food Standards Agency contained glyphosate residues [9]. Three samples had 0.5 parts per million of glyphosate [9], a relatively high level compared to the other pesticides found in these bread samples.

Budget pressures have forced the U.S. Department of Agriculture to reduce the number of crops included in its annual NASS pesticide use survey. Soybean pesticide use has not been surveyed since 2006, about when the spread of glyphosate-resistant weeds began to significantly increase herbicide use in selected areas. Herein, total herbicide use on HR hectares is projected to rise 13.5\% from 2006-2011 (about 2.7\% annually), compared to a $6.6 \%$ (1.3\% annually) increase on conventional soybean hectares. By way of contrast, the NASS-reported glyphosate rate of application per crop year on the average hectare of soybeans increased $8.9 \%$ per annum from 2000-2006 (see Table 1). So, despite the significant and widespread challenges inherent in managing glyphosateresistant weeds in the 2006-2011 period, a substantial decrease is projected in the rate of increase in glyphosate applications per hectare of HR soybeans. The justification for this projected fall in the rate of increase is recognition by farmers that further increases in glyphosate use will likely not prove cost-effective, coupled with positive responses by farmers to the near-universal recommendation that corn-soybean farmers incorporate into their spray programs herbicides that work through modes of action other than glyphosate's [10-15].

Since 1996, about 317 million trait hectares (782 million trait acres) have been planted to the three major $B t$ traits - Bt corn for European corn borer (ECB) and $\mathrm{CRW}$, and $B t$ cotton. $B t$ corn and cotton have delivered consistent reductions in insecticide applications totaling 56 million kgs (123 million pounds) over 16 years of commercial use. $B t$ corn reduced insecticide use by 41
Table 1 Projected rates of change in herbicide use since the most recent USDA survey, relative to recent annual percent changes in rates

\begin{tabular}{lccc}
\hline & $\mathbf{2 0 1 0 - 2 0 1 1}$ & $\mathbf{2 0 0 5 - 2 0 1 0}$ & Per Year 2005-2010 \\
\hline Corn & & & \\
Total Herbicides & $2 \%$ & $10.2 \%$ & $2.0 \%$ \\
Glyphosate & $2.5 \%$ & $12.9 \%$ & $2.6 \%$ \\
Soybeans & $\mathbf{2 0 0 7 - 2 0 1 1}$ & $\mathbf{2 0 0 0 - 2 0 0 6}$ & Per Year 2000-2006 \\
Total Herbicides & $3.2 \%$ & $35.2 \%$ & $5.9 \%$ \\
Glyphosate & $3.3 \%$ & $53.4 \%$ & $8.9 \%$ \\
\multicolumn{1}{c}{ Cotton } & $\mathbf{2 0 1 0 - 2 0 1 1}$ & $\mathbf{2 0 0 7 - 2 0 1 0}$ & Per Year 2007-2010 \\
Total Herbicides & $2.2 \%$ & $3.1 \%$ & $1.0 \%$ \\
Glyphosate & $-1 \%$ & $-10.3 \%$ & $-3.4 \%$ \\
\hline
\end{tabular}

million kgs (90 million pounds), while Bt cotton displaced 15 million kgs (34 million pounds) of insecticide use.

Taking into account applications of all pesticides targeted by the traits embedded in the three major GE crops, pesticide use in the U.S. was reduced in each of the first six years of commercial use (1996-2001). But in 2002, herbicide use on HR soybeans increased 8.6 million $\mathrm{kgs}$ (19 million pounds), driven by a $0.2 \mathrm{kgs} / \mathrm{ha}$ (0.18 pounds/acre), increase in the glyphosate rate per crop year, a 21\% increase. Overall in 2002, GE traits increased pesticide use by 6.9 million kgs (15.2 million pounds), or by about $5 \%$. Incrementally greater annual increases in the kilograms/pounds of herbicides applied to HR hectares have continued nearly every year since, leading to progressively larger annual increases in overall pesticide use on GE hectares/acres compared to non-GE hectares/acres. The increase just in 2011 was 35.3 million $\mathrm{kgs}$ (77.9 million pounds), a quantity exceeding by a wide margin the cumulative, total 14 million $\mathrm{kg}$ (31 million pound) reduction from 1996 through 2002.

Total pesticide use has been driven upward by 183 million kgs (404 million pounds) in the U.S. since 1996 by GE crops, compared to what pesticide use would likely have been in the absence of $\mathrm{HR}$ and $B t$ cultivars. This increase represents, on average, an additional $\sim 0.21$ $\mathrm{kgs} / \mathrm{ha}(\sim 0.19$ pounds/acre) of pesticide active ingredient for every GE-trait hectare planted. The estimated overall increase of 183 million kgs (404 million pounds) applied over the past 16 years represents about a $7 \%$ increase in total pesticide use.

There are two major factors driving the upward trend in herbicide use on HR hectares compared to hectares planted to non-HR crops: incremental reductions in the application rate of herbicides other than glyphosate applied on non-HR crop hectares, and second, the emergence and rapid spread of glyphosate-resistant weeds. The first factor is driven by progress made by the 
pesticide industry in discovering more potent herbicidal active ingredients effective at progressively lower rates of application.

Twenty-seven percent of U.S. soybean hectares in 1996 were treated with pendimethalin at an average rate of 1.1 $\mathrm{kgs} / \mathrm{ha}$ and another $22 \%$ were sprayed with trifluralin at a rate of $0.99 \mathrm{kgs} / \mathrm{ha}$, while the market leader (imazethapyr) was applied to $43 \%$ of hectares planted at a rate of 0.07 $\mathrm{kgs} / \mathrm{ha}$ [16]. By 2002 the combined percentage of soybean hectares treated with these two high-dose herbicides had dropped from $49 \%$ to $16 \%$ [17], and just 5\% were treated in 2006 [18]. Between 1996 and 2006, the number of registered soybean herbicides applied at rates below $0.11 \mathrm{kgs} /$ ha increased from nine to 17. As a result, the amount of herbicides applied to conventional crops has steadily fallen since 1996. In contrast, glyphosate is a relatively high-dose herbicide that is usually applied at a rate between 0.67 to $0.9 \mathrm{kgs}$ per hectare.

\section{Resistant weeds}

The emergence and spread of glyphosate-resistant weeds is the second, and by far most important factor driving up herbicide use on land planted to herbicide-resistant varieties. Glyphosate resistant (GR) weeds were practically unknown before the introduction of RR crops in 1996. The first glyphosate-resistant weed (Lolium rigidum) emerged in Australia in 1996 from canola, cereal crop, and fence line applications [19]. In the mid-1990s, as the first glyphosate-resistant crops were moving toward commercialization and gaining market share, Monsanto scientists wrote or were co-authors on several papers arguing that the evolution of GR weeds was unlikely, citing the herbicide's long history of use ( $\sim 20$ years) and relative absence of resistant weeds $[20,21]$.

Other scientists, however, challenged this assertion [22]. Dr. Ian Heap, long-time manager of the international database on resistant weeds, warned in a 1997 conference presentation that to limit glyphosate selection pressure in Roundup Ready cropping systems, the herbicide would need to be used in conjunction with proven resistancemanagement practices and with non-chemical weed control methods [23]. A 1996 report by Consumers Union stated that HR crops are "custom-made" for accelerating resistance and called for the Environmental Protection Agency (EPA) to revoke approval of HR crops when and where credible evidence of resistance emerges [24].

Today, the Weed Science Society of America (WSSA) website lists 22 GR weed species in the U.S. [19]. Over two-thirds of the approximate 70 state-GR weed combinations listed by WSSA have been documented since 2005, reflecting the rapidly spreading nature of the GR-weed problem. According to the WSSA, over 5.7 million hectares (14 million acres) are now infested by GR weeds, an estimate that substantially underestimates the actual spread of resistant weeds [16,22], [and personal communication, Dr. Ian Heap]. Dow AgroSciences carried out a recent survey on the percent of crop acres/hectares in the U.S. impacted by glyphosate-resistant weeds [25]. Findings from the survey were provided to USDA in support of Dow AgroSciences's petition for deregulation of 2,4-D herbicide-resistant corn, and suggest that around 40 million hectares (100 million acres) are already impacted by glyphosate-resistant weeds, an estimate that Heap considers inflated [personal communication]. The true extent of spread in the U.S. likely lies around the midpoint between the WSSA and Dow AgroSciences estimates (i.e., 20-25 million hectares), and by all accounts, will continue to rise rapidly for several years.

Why have GR weeds become such a serious problem? Heavy reliance on a single herbicide - glyphosate (Roundup) - has placed weed populations under progressively intense, and indeed unprecedented, selection pressure [10]. HR crops make it possible to extend the glyphosate application window to most of the growing season, instead of just the pre-plant and post-harvest periods. HR technology allows multiple applications of glyphosate in the same crop year. The common Midwestern rotation of HR corn-HR soybeans, or HR soybeans-HR cotton in the South, exposes weed populations to annual and repetitive glyphosate-selection pressure.

These factors trigger a perfect storm for the emergence of GR weeds. Research has traced the resistance mechanism in Palmer amaranth (Amaranthus palmeri) to 5-enolpyruvylshikimate-3-phosphate synthase (EPSPS) gene amplification. Resistant weed populations from Georgia contained 5-fold to 160-fold more copies of the EPSPS gene, compared to susceptible plants [26]. Moreover, EPSPS gene amplification is heritable, leading Gaines et al. to warn that the emergence of GR weeds "endangers the continued success of transgenic glyphosate-resistant crops and the sustainability of glyphosate as the world's most important herbicide."

Resistant Palmer amaranth (Amaranthus palmeri) has spread dramatically across southern states since the first resistant populations were confirmed in 2005, and already poses a major economic threat to U.S. cotton production. Some infestations are so severe that cotton farmers have been forced to leave some crops unharvested.

\section{Responding to resistance}

GR weed phenotypes are forcing farmers to respond by increasing herbicide application rates, making multiple applications of herbicides, applying additional herbicide active ingredients, deep tillage to bury weed seeds, and manual weeding. In recent years the first three of the above responses have been the most common. Each response increases the kilograms of herbicides applied on HR crop hectares. All five interventions increase costs. 
Moreover, if 2,4-D and dicamba herbicide-resistant corn and soybeans are fully deregulated by the U.S. government, there will be growing reliance on older, higher-risk herbicides for management of glyphosate-resistant weeds.

Based on an upward trajectory in the planting of 2,4-D HR corn reaching $55 \%$ of corn hectares planted by 2019 , coupled with an average of 2.3 applications (the label allows three) and an average rate of $0.94 \mathrm{kgs} / \mathrm{ha}(0.84$ pounds/acre) (the label allows $1.12 \mathrm{kgs} / \mathrm{ha}$ (1.0 pounds/ acre)), 2,4-D use on corn in the U.S. would increase over 30-fold from 2010 levels [Additional file 1: Table S19]. Such a dramatic increase could pose heightened risk of birth defects $[27,28]$ and other reproductive problems [29], more severe impacts on aquatic ecosystems [30], and more frequent instances of off-target movement and damage to nearby crops and plants. Moreover, the efficacy of 2,4-D corn may well prove short lived, since a population of 2,4-D resistant waterhemp (Amaranthus tuberculatus) has now been confirmed in Nebraska [31], and there are already at least eight other weeds resistant to 2,4-D [19].

GR weeds typically emerge first on a few isolated fields, but their pollen, genes, and seeds can travel widely and spread quickly, especially if glyphosate continues to be relied on heavily [11]. No substantial change in the intensity of glyphosate use in the U.S. is expected in the foreseeable future; nearly all corn, soybean, and cotton cultivars now carry a RR gene. The seed industry has no plans to grow and sell more non-HR seed, and indeed is moving in the opposite direction by developing more stacked, multiple HR varieties. The share of total national corn, soybean, and cotton hectares impacted by GR weed populations is likely to grow and will, as a result, increase both the number of different herbicides applied, as well as the total kgs of herbicides applied.

As argued by many weed scientists and extension specialists, integrated weed management systems, coupled with markedly lessened reliance on RR technology are now essential to extend the useful life of RR technology $[10,12,14,32]$. Without major change, a crisis in weed management systems is likely, triggering possibly ominous economic, public health, and environment consequences.

\section{Higher costs triggered by resistant weeds and $H R$ technology}

Weed management costs per hectare increase by $50 \%$ to $100 \%$ or more in fields infested with glyphosate-resistant weeds, as evident in a series of case studies submitted to the USDA by Dow AgroSciences in support of its petition to the USDA seeking deregulation of 2,4-D herbicideresistant corn [25]. In soybean production in Arkansas, for example, Dow AgroSciences compared the average cost/ acre of the top-five, most popular herbicide programs in Roundup Ready soybeans in fields without resistant weeds, compared to the average of two recommended programs in fields infested with glyphosate-resistant Palmer amaranth. Herbicide costs rise 2.7-fold (from $\$ 16.29$ to $\$ 44.34$ per acre) [23], [Table thirty, page 93]. In Illinois soybean production, the increase in herbicide costs is estimated at 64\% (\$19.21 to $\$ 31.49$ per acre) [23], [Table thirty-two, page 95], while in Iowa corn production, the increase is $67 \%$ (\$19.23 to $\$ 32.10$ per acre) [23], [Table thirty-six, page 99].

The markedly higher cost/hectare of herbicideresistant seeds must be added to the higher herbicide costs noted above to more fully reflect the added costs associated with HR technology. The cost of a bushel of conventional, not-GE soybean seed increased during the GE-crop era from $\$ 14.80$ in 1996 to $\$ 33.70$ in 2010, while a bushel of GE soybean seed cost, on average, $\$ 49.60$ in 2010 (all seed price data derived from USDA data) [33]. Accordingly, the cost of GE soybean seed in 2010 was $47 \%$ higher per bushel than non-GE seed. In the case of corn, conventional seed prices rose from $\$ 26.65$ per acre planted in 1996 to $\$ 58.13$ in 2010. The average cost of GE corn seed per acre in 2010 was $\$ 108.50$, with some GE cultivars selling for over $\$ 120$ per planted acre. Hence, GE corn seed costs per acre were about double the cost conventional seed.

\section{Public health concerns}

Heightened risk of public health impacts can be expected in the wake of more intensive herbicide use, especially applications later in the season on herbicideresistant crop varieties. While current risk assessment science suggests that glyphosate is among the safer herbicides per hectare treated in terms of human health risks, both the frequency of human exposures and levels of exposure via food, drinking water, and the air have no doubt risen in the U.S. in recent years. Two-thirds to $100 \%$ of air and rainfall samples tested in Mississippi and Iowa in 2007-2008 contained glyphosate [34].

The likely approval and use of herbicide-resistant crops in the U.S. engineered to survive applications of multiple herbicides adds tricky new dimensions to herbicide-risk assessments. Applications later in the growing season will be more likely to lead to residues in silage or forage crops. As a result, herbicide residues in milk, meat, or other animal products might become more common. The jump in herbicide volumes applied during June and July will increase the risk of drift and herbicide movement via volatilization, possibly exposing people via the air, water, or crops grown in the proximity of treated fields. Risks from the drift and volatilization of 2,4-D and dicamba are of special concern, given that these two herbicides have triggered thousands of non-target crop damage episodes over the last 20 years in the U.S. Indeed, for several years, 
2,4-D has been the leading cause of crop damage episodes investigated by State departments of agriculture [35].

\section{Environmental impacts linked to HR technology}

A long list of environmental effects can be triggered, or made worse, by the more intensive herbicide use required to keep pace with weeds in farming systems heavily reliant on herbicide-resistant crops. Glyphosate has been shown to impair soil microbial communities in ways that can increase plant vulnerability to pathogens [36-38], while also reducing availability of certain soil minerals and micronutrients [39]. Landscapes dominated by herbicide-resistant crops support fewer insect and bird species; e.g., a study in the American Midwest reported a 58\% decline in milkweed and an 81\% drop in monarch butterflies from 1999 to 2010 [40]. Heavy use of glyphosate can reduce earthworm viability [41] and water use efficiency [42]. Several studies have documented reductions in nitrogen fixation in herbicide-resistant soybean fields sprayed with glyphosate $[43,44]$. Transgene flow from herbicide-resistant crops can occur via multiple mechanisms and can persist in weedy relatives [45].

Individually, these environmental impacts appear, for the most part, of the same nature and in the same ballpark as the risks associated with other herbicide-based farming systems, but collectively they raise novel concerns over long-term, possibly serious impacts on biodiversity, soil and plant health, water quality, aquatic ecosystem integrity, and human and animal health.

\section{Bt corn and cotton impacts and prospects}

While $B t$-transgenic corn and cotton have displaced an estimated 56 million kgs (123 million pounds) of insecticides since 1996, every plant in a $B t$ corn or cotton field is manufacturing within its cells one or more forms of the natural bioinsecticide Bacillus thuringiensis. The rate of synthesis of $B t$ Cry protein endotoxins is roughly proportional to the rate of plant growth. As plants mature and enter senescence, $B t$ endotoxin expression falls.

Few published estimates are available of $B t$ endotoxin expression levels in contemporary corn cultivars. Nguyen et al. projected that a hectare of Bt-corn for CRW control expressing the Cry3Bb1 gene in MON88017 corn produces 905 grams of Cry3Bb1 per hectare $(0.8$ pounds per acre) [46]. The amount of $B t$ Cry proteins produced by a hectare of $B t$ corn for ECB and CRW control are calculated in [Additional file 1: Tables S20-S22], with key results shown in Table 2 for specific corn events, traits, and endotoxins. [Additional file 1 Tables S23-25] cover Bt cotton events. Expression level data reported by companies in regulatory documents were used to calculate per hectare production of specific endotoxins. [Additional file 1: Tables S21 and Table S24 contain the expression level data for $B t$ corn and cotton events, and [Additional file 1: Table S22 and Table S25] report the volumes of Bt Cry proteins produced per hectare and acre based on contemporary seeding rates.

Major contemporary $B t$ corn events targeting the ECB synthesize nearly as much or more insecticidal Cry protein per hectare than the weighted-average rate of conventional

Table 2 Bt cry protein synthesis in major GE corn cultivars

\begin{tabular}{|c|c|c|c|c|c|c|c|c|}
\hline & $\begin{array}{c}\text { Cry } \\
\text { Protein }\end{array}$ & Cry/Shoot & Cry/Root & Cry/Plant & $\begin{array}{l}\text { Plants } \\
\text { per } \\
\text { hectare }\end{array}$ & $\frac{\text { Cry Toxin }}{\mathrm{kg} / \mathrm{ha}}$ & $\begin{array}{l}\text { Plants } \\
\text { per } \\
\text { Acre } \\
\end{array}$ & $\frac{\text { Cry Toxin }}{\text { lb/acre }}$ \\
\hline MON 810 & Cry1Ab & 1193 & 496 & 1689 & 79,040 & 0.133 & 32,000 & 0.119 \\
\hline MON 88017 & Cry3Bb1 & 14915 & 4030 & 18945 & 79,040 & 1.497 & 32,000 & 1.333 \\
\hline MON 89034 & Cry1A.105 & 2826 & 620 & 3446 & 79,040 & 0.272 & 32,000 & 0.242 \\
\hline MON 89034 & Cry2Ab2 & 4553 & 496 & 5049 & 79,040 & 0.399 & 32,000 & 0.355 \\
\hline TC 1507 & Cry1F & 1207 & 165 & 1372 & 79,040 & 0.108 & 32,000 & 0.097 \\
\hline DAS 59122 & Cry34Ab1 & 26376 & 2647 & 29023 & 79,040 & 2.294 & 32,000 & 2.042 \\
\hline DAS 59122 & Cr35Ab1 & 5825 & 567 & 6392 & 79,040 & 0.505 & 32,000 & 0.45 \\
\hline \multicolumn{9}{|l|}{ SmartStax Corn } \\
\hline MON 88017 & Cry3Bb1 & 7536 & 2015 & 9551 & 79,040 & 0.755 & 32,000 & 0.672 \\
\hline MON 89034 & Cry1A.105 & 2983 & 651 & 3634 & 79,040 & 0.287 & 32,000 & 0.256 \\
\hline MON 89034 & Cry2Ab2 & 4553 & 558 & 5111 & 79,040 & 0.404 & 32,000 & 0.36 \\
\hline TC 1507 & Cry1F & 1413 & 185 & 1598 & 79,040 & 0.126 & 32,000 & 0.112 \\
\hline DAS 59122 & Cry34Ab1 & 24649 & 2623 & 27272 & 79,040 & 2.156 & 32,000 & 1.918 \\
\hline DAS 59122 & Cr35Ab1 & 5275 & 586 & 5861 & 79,040 & 0.463 & 32,000 & 0.412 \\
\hline SmartStax Total & & & & & & 4.191 & & 3.73 \\
\hline
\end{tabular}


insecticides applied on a hectare planted to $B t$ corn for ECB control (about $0.15 \mathrm{kgs}$ insecticide per ha; 0.13 pounds/acre in 2010 [Additional file 1: Table S11]). MON810, the Cry protein in Monsanto's original Yieldgard corn, expresses $0.2 \mathrm{kgs} / \mathrm{ha}$ of endotoxin, whereas Syngenta's Bt 11 synthesizes $0.28 \mathrm{kgs} / \mathrm{ha}$ [Additional file 1: Table S22]. Newer events for ECB control like Monsanto's Genuity VT Double PRO (MON 89034) produce Cry 1A.105 and Cry 2Ab2 endotoxins totaling $0.62 \mathrm{kgs} / \mathrm{ha}$. The Dow AgroSciences-Pioneer Hi-Bred Herculex I (TC1507) event expresses the least endotoxin $-0.1 \mathrm{~kg} \mathrm{Bt}$ endotoxin per hectare - just below the rate of insecticides applied.

In the case of $B t$ corn targeting the CRW, every hectare planted in recent years expresses substantially greater volumes of $B t$ endotoxins than the $\sim 0.2 \mathrm{kgs}$ of insecticides applied on the average hectare for CRW control (0.19 pounds/acre [Additional file 1: Table S12]). MON 88017 expresses $0.62 \mathrm{kgs} / \mathrm{ha}$ of Cry 3Bb1, while DAS 59122-7 expresses two Cry proteins totaling $2.8 \mathrm{kgs} / \mathrm{ha}, 14$-fold more than the insecticides displaced [Additional file 1: Table S22]. SmartStax GE corn synthesizes six Cry proteins, three targeting the ECB, and three the CRW. Total Cry protein production is estimated at $4.2 \mathrm{kgs} / \mathrm{ha}(3.7$ pounds/acre), 19-times the average conventional insecticide rate of application in 2010.

\section{Should Bt endotoxins count as insecticides applied?}

Entomologists are divided on the question of whether the $B t$ produced by transgenic plants should be counted as "insecticides applied." The case for doing so is strong, despite the obvious differences in how Cry proteins enter corn agroecosystems. When a field of corn is sprayed with a foliar $B t$ insecticide, the amount of toxin sprayed per hectare should be counted when computing total insecticide use. The primary difference between the Bt Cry proteins in a $B t$-transgenic plant, and a field of non-GE plants sprayed with foliar $B t$, is that in the later case, the toxin is present predominantly on plant tissue surfaces, whereas in the former $B t$-crop case, the toxin is inside plant cells. This distinction does not greatly matter from the perspective of the overall load of pesticides in the environment, although the presence of pesticides inside plants, as opposed to on their surface, alters relative risk profiles across non-target organisms.

It should also be noted that, in general, the systemic delivery of $B t$ Cry proteins poses more significant risks to animals and humans ingesting $B t$ crops than applications of $B t$ insecticides via liquid sprays. Systemic delivery also enhances a range of environmental and ecological risks [47] compared to foliar $B t$ use patterns that result in rapid breakdown of $B t$ Cry proteins as they are exposed to sunlight and rainfall.
Most corn insecticides are applied in ways that expose active ingredients to destructive abiotic and biotic forces that tend to break down the chemicals to generally less toxic forms. Granular soil insecticides applied via boxes on corn planters tend to break down within weeks as a result of soil microbial activity. Because properly applied granular insecticides are buried in the soil, exposure to non-target organisms is limited, although poorly operated or calibrated planting equipment can result in grains of insecticide remaining on the soil surface, posing a serious potential risk to some bird species. A significant portion of the foliar insecticides applied per hectare for ECB control never hit its plant target, and a portion of the insecticide that does land and lodge on plant tissues is washed off within hours, days, or weeks during rainfall events. This is why insecticide residues are rarely detected in corn grain and silage at harvest time, and why conventional insecticide applications on corn pose little or no human dietary risk.

By virtue of their altered environmental fate and risk profile, all systemic pesticides should be counted when measuring pesticide use, and hence so too should the $B t$ proteins manufactured in Bt-transgenic crops. If $B t$-transgenic plants produced proteins that disrupted insect morphology, feeding behavior, or reproduction, the absence of a toxic mode of action would strengthen the argument that $B t$ Cry proteins are not functionally equivalent to insecticides, and hence should not be counted as insecticides applied. Bt-crop technology that limits Bt-endotoxin expression to only those tissues that are under active attack, and then only during times when insects are actively feeding, would also support the view that $B t$ crops are compatible with IPM.

\section{Conclusions}

Today's pest-management related GE traits have proven popular and commercially profitable for the biotechseed industry, but over-reliance has set the stage for resistance-driven problems in both herbicide-resistant and Bt-transgenic crops. Largely because of the spread of glyphosate-resistant weeds, HR crop technology has led to a 239 million $\mathrm{kg}$ (527 million pound) increase in herbicide use across the three major GE-HR crops, compared to what herbicide use would likely have been in the absence of HR crops. Well-documented increases in glyphosate applications per hectare of HR crop account for the majority of this 239 million $\mathrm{kg}$ increase.

While $B t$ corn and cotton have reduced insecticide applications by 56 million kgs (123 million pounds), resistance is emerging in key target insects and substantial volumes of $B t$ Cry endotoxins are produced per hectare planted [corn, Additional file 1: Tables S20-S22, cotton, Additional file 1: Tables S23-S25], generally dwarfing the volumes of insecticides displaced. Documenting the 
full range of impacts on the environment and public health associated with the $B t$ Cry proteins biosynthesized inside $B t$-transgenic plants remains a challenging and largely ignored task, especially given the recent move toward multiple $B t$ protein, stacked-trait events.

Overall, since the introduction of GE crops, the six major GE technologies have increased pesticide use by an estimated 183 million kgs (404 million pounds), or about 7\%. The spread of GR weeds is bound to trigger further increases, e.g., the volume of 2,4-D sprayed on corn could increase $2.2 \mathrm{kgs} / \mathrm{ha}$ by 2019 (1.9 pounds/acre) if the USDA approves unrestricted planting of 2,4-D HR corn [Additional file 1: Table S19]. The increase in herbicides applied on HR hectares has dwarfed the reduction in insecticide use over the 16 years, and will almost surely continue to do so for several more years.

Estimating the impacts of GE crops on pesticide use is growing more complex because of gaps in NASS pesticide use data collection for the three major crops, increases in the average number of traits per GE-crop hectare planted, the registration of HR crops engineered to resist herbicides other than glyphosate, massive disruption in weed communities, and the presence of one to three, or even more, glyphosate-resistant weeds in many crop fields. It is difficult to project what the distribution, population levels, and phenotypes of weeds would have been over the last 16 years in the absence of HR technology. Inevitably, weed management systems and technology would have evolved along other trajectories in the absence of HR crops these last 16 years, resulting in heightened reliance on both preplant and post-emergence applications of multiple, lowdose herbicides.

A majority of American soybean, maize, and cotton farmers are either on, or perilously close to a costly herbicide and insecticide treadmill. Farmers lack options and may soon be advised, out of necessity, to purchase HR crop cultivars resistant to multiple active ingredients and to treat $B t$ corn with once-displaced corn insecticides. The seed-pesticide industry is enjoying record sales and profits, and the spread of resistant weeds and insects opens up new profit opportunities in the context of the seed industry's current business model. Regulators cannot restrict the use of a previously approved HR technology because it increases pesticide use and triggers resistance, nor have U.S. government agencies turned down an application for a new HR or Bt-transgenic trait because of the likelihood it would accelerate the spread of resistant weeds or insects. Whether the USDA has the statutory authority to deny a petition for HR crop deregulation (i.e., approval) on the grounds of worsening problems with resistant weeds is a contested issue in ongoing litigation.

Profound weed management system changes will be necessary in the three major GE crops to first stabilize, and then hopefully reduce herbicide use, the costs of weed management, and herbicide-related impacts on human health and the environment. Weed management experts are largely in agreement that the percent of cropland area planted to glyphosate-based HR seeds must decline dramatically (e.g., by at least one-third to one-half) for farmers to have a realistic chance at success in preventing resistance $[10,12,14]$. Unfortunately, there appears little interest across the seed-biotech industry in increasing production of non-Roundup Ready or not- $B t$ transgenic seed. Since the decisions made by the seed industry in any given year determine the traits offered by the industry to farmers in next crop season, the seed industry must act first in order for farmers to turn the corner toward more sustainable weed and insect pest management systems. The many important ramifications of this practical reality - that the seed industry must act first - have yet to be fully appreciated by farmers, weed management experts, and policy makers in the U.S.

Regulators in the U.S. have thus far done little to prevent the emergence and spread of resistant weeds, while several resistance-management interventions have been imposed as part of the approval of $B t$ crops. In addressing weed resistance, the hands-off regulatory posture in the U.S. reflects, in part, the basic authorities granted to the EPA and USDA in federal law. Both agencies regard weed resistance as an efficacy-economics challenge that can best be addressed by the private sector consistent with market forces. The need for novel policy interventions will grow in step with the emergence and spread of resistance weeds and evidence of adverse economic, environmental, and public health consequences triggered by markedly increasing reliance on older, higher-risk herbicides.

\section{Methods}

The model calculates the impact of HR and Bt-transgenic crop varieties on pesticide use annually from 1996 through 2011, and aggregates results over this 16-year period. The model is composed of 16 tables [Additional file 1: Tables S1-S16]. Nine additional tables, [Additional file 1: Tables S17-S25] address changes in pesticide use, the spread of resistant weeds, and the quantity of $B t$ endotoxins produced per hectare by today's major corn and cotton $B t$ traits.

The model was developed using the units of measure typical in USDA-NASS surveys (pounds of active ingredients, acres planted); the Additional files are available in pounds and acres units only. In this paper, metric units are used to report results, although selected key results will be reported in both units of measure.

[Additional file 1: Table S1] records average per acre herbicide and insecticide use data, drawing on pesticide use data compiled annually by the USDA's NASS. These surveys record the percent of crop acres treated with 
specific active ingredients, average one-time rates of application, the average number of applications, the rate per crop year (average rate multiplied by the average number of applications), and total pounds applied.

In the case of herbicides, [Additional file 1: Table S1] reports total herbicide, all glyphosate, and "Total Herbicides Minus Glyphosate." "All Glyphosate" aggregates the multiple chemical forms of glyphosate surveyed by NASS, and calculates average rates of application and number of applications, weighted by frequency of use. The same procedure is used to calculate average pounds/acre applied of other herbicides of interest for which NASS reports use data for multiple chemical forms (e.g. 2,4-D, dicamba). [Additional file 1: Table S2] includes national acres planted to each crop, average pesticide use rates, and total pounds applied per acre and overall herbicide, insecticide, and herbicide + insecticide volumes applied.

[Additional file 1: Tables S3-S6] record the percent of national acres planted to a crop variety expressing each of the six, major commercial GE traits. The USDA's ERS provides data on the percent of total national corn [Additional file 1: Table S3], soybean [Additional file 1: Table S4], and cotton hectares [Additional file 1: Table S5] that were planted to each GE crop trait for 19962011. Percent acres planted to all six GE traits by year are presented in [Additional file 1: Table S6]; there is a high level of confidence in these data.

[Additional file 1: Table S7] reports acres planted to each of the six traits, multiplying the percent acres planted to each trait in ST 6 by total acres planted to each crop in [Additional file 1: Table S2]. [Additional file 1: Tables S8-S10] calculate, for the three HR crops, the estimated difference in average herbicide use on HR hectares versus land planted to conventional, non-GE varieties. [Additional file 1: Tables S11-S13] report the basis for calculating the pounds of insecticides displaced by the planting of $B t$ corn and cotton traits. [Additional file 1: Table S14] integrates all of the average per acre pesticide use rates by crop, trait and year, and reports the estimated difference between per acre rates on GE versus non-GE acres. [Additional file 1: Table S15] converts the differences in rates per acre to differences in pounds applied nationally by crop, trait, and year, and over the 16-year period. [Additional file 1: Table S16] provides details on glyphosate use from NASS surveys over the 1996-2010 period, and is the source of data on glyphosate use in other Additional files.

\section{Assumptions, projections, and calculations}

A series of assumptions, projections, and calculations are embedded in the model in order to estimate total herbicide and insecticide use on GE versus not-GE hectares. Table 3 outlines model assumptions and Table 4 describes the projections embedded in the model's calculations.

NASS surveyed corn, soybean, and cotton pesticide use in most years from 1996-2010. None of the crops were surveyed in 2008; cotton was last surveyed in 2007 and 2010; corn was surveyed in 2005 and 2010; and soybeans have not been surveyed since 2006. In estimating the impacts of GE crops on pesticide use from 19962011, average application rates per crop year were interpolated in years with no data, when NASS had surveyed a previous and subsequent year, based on the assumption of linear change in the intervening years.

It is assumed that changes in the volume of herbicides other than glyphosate applied on the average HR hectare tracks changes in total herbicide use, and also changes gradually from year-to-year. With few exceptions, these

Table 3 Data sources and assumptions required to quantify the impact of GE crops on pesticide use in the U.S., 19962011

\begin{tabular}{|c|c|c|c|}
\hline Parameter & Source & $\begin{array}{l}\text { Supplemental } \\
\text { table impacted }\end{array}$ & Basis and explanation \\
\hline $\begin{array}{l}\text { National Pesticide Use per Acre/ } \\
\text { Hectare }\end{array}$ & NASS-USDA & 1,2 & $\begin{array}{l}\text { Best publicly available estimates of annual per acre herbicide } \\
\text { and insecticide use }\end{array}$ \\
\hline $\begin{array}{l}\text { Annual Gaps in NASS Survey } \\
\text { Data by Crop }\end{array}$ & Interpolated & 1,2 & $\begin{array}{c}\text { Changes in total herbicide, glyphosate, and insecticide use } \\
\text { occur linearly/annum when there are gaps in NASS pesticide } \\
\text { use surveys }\end{array}$ \\
\hline $\begin{array}{l}\text { Annual Application Rates of } \\
\text { "Other Herbicides on HR } \\
\text { Hectares" }\end{array}$ & (See Table 4) & $8,9,10$ & $\begin{array}{l}\text { Trends by crop on HR acres track changes in total herbicide use, } \\
\text { as reported by NASS; changes from year to year are gradual }\end{array}$ \\
\hline $\begin{array}{l}\text { Bt Cry Proteins Produced by Bt } \\
\text { Corn and Cotton Plants }\end{array}$ & $\begin{array}{l}\text { Projected (see text, } \\
\text { Additional files) }\end{array}$ & $20-25$ & $\begin{array}{c}\text { Trait-specific expression levels by tissue taken from documents } \\
\text { submitted by technology developers; used to quantify } \\
\text { volume of each Bt endotoxin produced by plants per acre/hectare } \\
\text { based on typical planting density }\end{array}$ \\
\hline Insecticide Use on Bt Corn & (Details in Table 4) & 11,12 & $\begin{array}{l}\text { Insecticide displacement as a result of planting Bt corn corrected } \\
\text { for hectares not likely to have been treated in the absence of } \\
\text { Bt corn cultivars }\end{array}$ \\
\hline Insecticide Use on Bt Cotton & NASS-USDA & 13 & $\begin{array}{l}\text { Budworm/bollworm control insecticide displacement on } \\
\text { hectares planted to Bt cotton is } 100 \%\end{array}$ \\
\hline
\end{tabular}


patterns of change in herbicide use are evident in all crops surveyed by USDA. Significant annual changes in total herbicide use, as well as non-glyphosate applications, are almost always linked to an increase or decrease in acres treated with one or more relatively high-dose herbicides applied at or around 1 pound/acre, compared to use of herbicides applied at rates less than 0.5 pound/acre (several are sprayed at rates below 0.05 pounds/acre).

The volumes of Bt Cry endotoxins produced per acre/ hectare of $B t$ corn and cotton are not included in the estimates of changes in insecticide use on acres/hectares planted to $B t$ cultivars, although the volumes are surprisingly significant compared to the volume of insecticides applied on treated acres/hectares (see "Discussion"). In the case of insecticide use on $B t$ corn, the volume of insecticide use displaced per acre/hectare is adjusted in light of the likely percent of $B t$ corn acres/hectares that would have been treated with an insecticide in the absence of $B t$ cultivars. Multiple analysts have reported substantial planting of $B t$ corn as insurance against possible insect feeding damage, on acres/hectares that farmers would not prophylactically apply insecticides [4,13]. In a January 2010 survey, $73.3 \%$ of 518 farmers surveyed at regional extension meetings in Illinois reported that they planted $B t$ corn "Knowing That Anticipated Damage Levels Were Low" [48]. USDA has surveyed corn insecticide use 14 times since 1991. The total area treated with an insecticide has fallen in the range $31 \%+/-5 \%$ in all years, with the average around $33 \%$.

It is assumed that farmers planting $B t$ cotton do not spray conventional insecticides against the budworm/bollworm complex of insecticides, leading to $100 \%$ displacement of such applications. This assumption likely overestimates displacement marginally, especially in recent years where isolated populations of less susceptible or resistant populations have emerged.

Table 3 describes the basis for projecting a number of missing values over the 1996-2011-time period. In the years since the last NASS survey, pesticide rates were projected based on recent trends and changes in weed pressure.

In the case of corn, total herbicide and glyphosate use trends from 2005-2010 are projected to continue unchanged through 2011, despite the accelerating emergence and spread of resistant weeds in the Midwest. The rapid rate of increase in total herbicide and glyphosate use/acre in soybean production systems from 20002006 (5.9\% and 8.9\%/annum) is projected to decline to an average increase of $3.2 \%$ and $3.3 \%$ per annum in 2007-2011. Reductions in annual rates of increase reflect the decision by many HR soybean farmers to follow the advice of weed management specialists $[10,11]$ to diversity the modes of action included in herbicide-based control programs. The rate of increase in total herbicide use on HR cotton from 2010 to 2011 is projected at about twice the annual rate, 2007-2010, whereas the rate of decline in per hectare glyphosate use is projected to fall from $-3.4 \%$ to $-1 \%$ per annum as farmers increase rates and/or frequency of applications of glyphosate in regions where resistant weeds are now posing serious management challenges.

\section{Estimating herbicide use on conventional and HR hectares}

NASS surveys do not report pesticide use on GE and conventional crop hectares separately.

The volume of herbicides applied to HR hectares can be approximated by adding NASS-reported glyphosate use

Table 4 Projections required quantifying the impact of GE crops on insecticide use in the US, 1996-2011

\begin{tabular}{|c|c|c|c|}
\hline Parameter & $\begin{array}{l}\text { Supplemental } \\
\text { table(s) } \\
\text { impacted }\end{array}$ & Basis for setting value & Basis and explanation \\
\hline \multicolumn{4}{|l|}{ Corn } \\
\hline $\begin{array}{l}\text { Share of Insecticide Applications } \\
\text { Targeting the European Corn Borer } \\
\text { (ECB) Versus Corn Rootworm (CRW) }\end{array}$ & 11,12 & $\begin{array}{l}\text { Guidance from extension IPM } \\
\text { specialists and land grant } \\
\text { university spray guides }\end{array}$ & $\begin{array}{c}\text { Some insecticides applied exclusively for control of ECB, } \\
\text { others for control of CRW; and some target both. The } \\
\text { percent hectares treated with a given insecticide are } \\
\text { apportioned relative to target pests: ECB, CRW, or other } \\
\text { insects. }\end{array}$ \\
\hline $\begin{array}{l}\text { "Other Insecticides" Applied in } 2010 \text { for } \\
\text { ECB Control }\end{array}$ & 11 & $\begin{array}{c}\text { NASS data on "Other } \\
\text { Insecticides" applied in } 2010\end{array}$ & $\begin{array}{c}\text { NASS reported } 237,000 \text { pounds of "Other Insecticide" use } \\
\text { in 2010; } 30 \% \text { of these "Other Insecticides" applied to corn } \\
\text { in } 2010 \text { projected to target the ECB. }\end{array}$ \\
\hline $\begin{array}{l}\text { "Other Insecticides" Applied in } 2010 \text { for } \\
\text { CRW Control }\end{array}$ & 12 & $\begin{array}{c}\text { NASS data on "Other } \\
\text { Insecticides" applied in } 2010\end{array}$ & $\begin{array}{c}\text { NASS reported } 237,000 \text { pounds of "Other Insecticide" use } \\
\text { in 2010; } 60 \% \text { of "Other Insecticides" applied to corn in } \\
2010 \text { projected to target the CRW. }\end{array}$ \\
\hline \multicolumn{4}{|l|}{ Cotton } \\
\hline $\begin{array}{l}\text { Share of Insecticide Applications } \\
\text { Targeting the Budworm/Bollworm } \\
\text { Complex }\end{array}$ & 13 & $\begin{array}{l}\text { Guidance from extension IPM } \\
\text { specialists and land grant } \\
\text { university spray guides }\end{array}$ & $\begin{array}{l}\text { Some insecticides applied exclusively or partly for control } \\
\text { of the budworm/bollworm complex, others for other } \\
\text { insects; percent hectares treated with a given insecticide } \\
\text { is apportioned relative to target insects. }\end{array}$ \\
\hline
\end{tabular}


per crop year to an estimate of the volume of herbicides other than glyphosate (hereafter, "other herbicides") applied on HR hectares. The volume of "other herbicides" applied on HR hectares is estimated based on the average number of non-glyphosate herbicides applied per hectare, coupled with the average rate per application of nonglyphosate herbicides. In addition, the rate of "other herbicides" on HR hectares is adjusted to reflect changes from year to year in overall herbicide use and glyphosate application rates. For example in recent years, "other herbicides" have been applied to around one-half of HR soybean hectares at an average rate of $\sim 0.34 \mathrm{kgs} / \mathrm{ha}(\sim 0.3$ pounds/acre), resulting in an average $\sim 0.17 \mathrm{kgs} / \mathrm{ha}(\sim 0.15$ pounds/acre) of "other herbicide" applications on all HR hectares $(0.5 \times 0.34)$.

The shares of total crop hectares in a given year planted to conventional and HR crop varieties is compiled by the USDA's ERS [Additional file 1: Tables S3-S5] and can be used in a weighted-average formula to calculate the kgs of herbicides applied on non-HR hectares -

$$
\begin{aligned}
\text { THA Crop } & =\left[\left(\% \operatorname{HPHT}_{x}\right) x\left(\mathrm{HAHT}_{x}\right)\right] \\
& +\left[\left(\% \mathrm{HPCON}_{x}\right) x\left(\mathrm{HACON}_{x}\right)\right]
\end{aligned}
$$

Where,

THA Crop ${ }_{\mathrm{x}}=$ "Total Herbicides Applied" (kgs active ingredient/hectare in a crop year);

$\% \mathrm{HPHT}_{\mathrm{x}}=$ Percent national "Hectares Planted to HR" cultivars;

$\mathrm{HAHT}_{\mathrm{x}}=$ "Herbicides Applied on HR" hectares (kg a. i./crop year);

$\% \operatorname{HPCON}_{\mathrm{x}}=$ Percent national "Hectares Planted to Conventional" non-HR hectares; and

$\mathrm{HACON}_{\mathrm{x}}=$ "Herbicides Applied on Conventional" hectares (kgs a.i./crop year).

The first four of the above-five variables are reported or can be derived from USDA data; the fifth can be calculated by solving the above equation for $\mathrm{HACON}_{\mathrm{x}}$. For each HR crop and year combination, the impact of HR cultivars on average herbicide use is calculated by subtracting $\mathrm{HAHT}_{\mathrm{x}}$ from $\mathrm{HACON}_{\mathrm{x}}$. This difference is then multiplied by the HR hectares planted, to calculate the impact of HR crops on herbicide use in a given year. Increases or decreases in the volume of herbicides applied as a result of the planting of HR crops are then aggregated across all years (1996-2011) and the three HR crops.

In the case of $B t$ transgenic corn, the average rate of application of insecticides targeting the ECB and the CRW must be calculated. This process is complicated by the fact that several insecticides are applied for control of the ECB and CRW, as well as other insects. Pesticide labels, treatment recommendations in university spray guides, and experts in corn Integrated Pest Management (IPM) were consulted in carrying out this step [Additional file 1: Tables S11, S12].

Average rates of insecticide application across all corn hectares treated per crop year are then calculated, weighted by portions of total hectare treatments. This weightedaverage rate of insecticide application on hectares treated for ECB control declines from $0.24 \mathrm{kgs} / \mathrm{ha}(0.21$ pounds/ acre) of active ingredient in 1996 to $0.15 \mathrm{kgs} / \mathrm{ha}(0.13$ pounds/acre) in 2010. In the case of CRW insecticides, the rate falls from $0.76 \mathrm{kgs} / \mathrm{ha}$ in 1996 to $0.2 \mathrm{kgs} / \mathrm{ha}$ in 2010 .

The next step in calculating the pounds of insecticides displaced by the planting of $B t$ corn is to estimate the portion of hectares planted to $B t$ corn for ECB and/or CRW control that would have been treated with an insecticide if the corresponding $B t$ crop had not been planted. Doing so requires a set of assumptions and projections.

Historically, USDA data shows that before the advent of Bt corn, $10 \%+/-3 \%$ of national corn hectares were treated for ECB control, while $27 \%+/-4 \%$ were treated for CRW control. Yet by 1998 (third year of commercial sales), $19 \%$ of corn hectares were planted to a $B t$ cultivar targeting the ECB - about double the historic share of hectares treated with an insecticide for this pest. Today, close to two-thirds of corn hectares are planted to $B t$ for ECB cultivars, some six-times the historic rate. In the case of $B t$ corn for CRW, by the fifth year of commercial sales, 2007, the share of corn hectares planted to CRW hybrids was $25.6 \%$, roughly equaling the historic share of hectares treated with CRW insecticides $(27 \%+/-4 \%)$. In 2011, $60 \%$ of corn hectares were planted to a CRW hybrid, double the historic share of corn hectares treated with a CRW insecticide.

The impact of $B t$ corn on the volume of insecticide displaced per hectare should be adjusted downward to account for hectares that would, in all likelihood, not have been treated. In the case of $B t$ corn targeting the ECB, the likely share of hectares planted to $B t$ corn that would have been sprayed for ECB control begins at 90\% in 1997, the first year of commercial planting, and drops incrementally to $45 \%$ in 2007 .

This percent is left unchanged from 2008-2010, despite the increase in corn hectares planted to Bt corn for ECB from $49 \%$ to $65 \%$, because of reported increases in insect pest pressure in major corn producing regions [49]. The result is the projection that in 2011, insecticide applications were displaced on 10.9 million hectares of corn (27 million acres) planted to $B t$ hybrids for ECB control (45\% of the $65 \%$ of corn hectares planted to $B t$ for ECB hybrids). These 10.9-million hectares are $29 \%$ of total corn hectares planted, and is about three-times the historic level of insecticide applications for ECB control.

In the case of $B t$ corn for CRW control, the percent of hectares planted that displaces insecticide use begins at $95 \%$ in 2003, the first year of commercial sales, and 
declines to $55 \%$ in 2011 . In $2011,57 \%$ of corn hectares were planted to a $B t \mathrm{CRW}$ hybrid, and hence $B t$ corn for CRW displaced insecticide use on $31 \%$ of national hectares planted. This estimate assumes that any hectare planted to a $B t$ corn for CRW control was not also treated with a CRW insecticide. In addition, 9.4\% of corn hectares were sprayed for CRW control with an insecticide. Accordingly, about $40 \%$ of corn hectares were either sprayed for the CRW or planted to a $B t$ variety for CRW control, well above the $27 \%+/-4 \%$ level treated with insecticide over the last 20 years.

The historically high, projected level of CRW treatment is justified, in part, by the emergence in the late 1990s of a variant of the CRW that learned to overwinter in soybean fields, thus undermining the efficacy of corn-soybean rotations in reducing CRW populations [50]. Recent, historically high corn prices have also increased the frequency of continuous corn, a management factor that surely has increased CRW pressure.

$B t$ cotton targets the budworm/bollworm complex, but does not affect other insect pests, including the boll weevil, plant bugs, white flies, and stinkbugs. Applications of broad-spectrum insecticides are typically made on essentially $100 \%$ of planted cotton hectares to control the budworm/bollworm complex and other insects. $B t$ cotton will reduce the use of insecticides on the budworm/bollworm complex, but will only indirectly impact applications of insecticides targeting other insects.

[Additional file 1: ST 13] reports the basis for estimating the pounds of insecticides displaced by each acre planted to $B t$ cotton. University insect management guides and experts were consulted to estimate the portion of hectares treated with each cotton insecticide that targeted the budworm/bollworm complex, versus other insects. The number of acres treated with each insecticide is calculated from NASS data, as well as the share of total acres treated. Average insecticide use rates are then calculated, weighted by each active ingredient's share of insecticide acre treatments targeting the budworm/bollworm complex. The weighted average cotton insecticide application rate falls modestly from $0.46 \mathrm{kgs} / \mathrm{ha}$ ( 0.41 pounds/acre) in 1997 to $0.27 \mathrm{kgs} / \mathrm{ha}(0.24$ pounds/acre) in 2010-2011.

Table 4 summarizes the basis for projections required to estimate the volume of insecticide use displaced by the planting of a hectare to $B t$ corn or cotton cultivars.

\section{Additional file}

Additional file 1: The projection model used is composed of a series of linked worksheets in a Microsoft Excel workbook. Each table within the workbook appears below in pdf as sequentially numbered Additional file 1: Table S1 (e.g., ST 1). The pesticide use data incorporated in the model were originally reported by U.S. government agencies in pounds of active ingredient, and/or pounds of a.i./acre, and so these units are used throughout the Additional files to report data on herbicide use. Convert pounds to kgs by multiplying by 0.454 ; to convert pounds/acre to $\mathrm{kg} / \mathrm{ha}$, multiply by 1.12 .

\section{Abbreviations}

Al: Active ingredient; Bt: Bacillus thuringiensis; CRW: Corn rootworm; ECB: European corn borer; EPSPS: Enolpyruvylshikimate-3-phosphate synthase; EPA: Environmental Protection Agency; ERS: Economic Research Service; GE: Genetically engineered, genetic engineering; GR: Glyphosate resistant; ha: Hectare; HR: Herbicide Tolerant; IPM: Integrated Pest Management; kgs: Kilograms; NASS: National Agricultural Statistics Service; NCFAP: National Center for Food and Agriculture Policy; RR: Roundup Ready; SI: International System of Units; ST: Supplemental Table; THA: Total hectares; US: United States; USDA: United States Department of Agriculture; WSSA: Weed Science Society of America.

\section{Competing interests}

The author declares he has no competing interests.

\section{Author contribution}

Charles Benbrook (CB) developed the model, carried out the analysis, and wrote the paper. The author read and approved the final manuscript.

\section{Author information}

$\mathrm{CB}$ is a Research Professor, Center for Sustaining Agriculture and Natura Resources, Washington State University, Pullman, Washington, USA. CB has studied the impacts of agricultural biotechnology since the mid-1980s in a variety of positions including Executive Director, Board on Agriculture, National Academy of Sciences/National Research Council, and as Chief Scientist, The Organic Center

\section{Acknowledgements}

Thanks to the analysts in the U.S. Department of Agriculture's (USDA) National Agricultural Statistics Service and the Economic Research Service (ERS) for compiling the data essential to carry out this work. Dr. Merritt Padgitt of the ERS (retired) carried out a special tabulation of USDA survey data on soybean pesticide use that was used to calibrate the model. Valuable assistance was provided in developing and refining the model and underlying dataset by Karen Benbrook and Karie Knoke. Dr. Margaret Mellon, Dr. Jane Rissler, and Dr. Doug Gurian-Sherman of the Union of Concerned Scientists (UCS) contributed to the conceptual development of the model. Mr. Bill Freese, Center for Food Safety, provided helpful suggestions and data on resistant weeds. Dr. Robert Kremer, Dr. Michael Gray, Dr. Matt Liebman, and Dr. Michael Owen are among the land grant pest management scientists that provided guidance as the model was developed. Funding to support the development of the model was provided by the Institute for Agriculture and Trade Policy, Consumers Union, UCS, and The Organic Center.

Received: 28 June 2012 Accepted: 3 September 2012

Published: 28 September 2012

\section{References}

1. Gassmann AJ, Petzold-Maxwell $\lrcorner$, Keweshan RS, Dunbar MW: Field-evolved resistance to Bt maize by western corn rootworm. PLoS One 2011, 6: e22629. doi:10.371/journal.pone.0022629.

2. Berry I: Illinois researcher confirms rootworm resistance to Monsanto corn trait. Wall Street Journal:: Dow Jones Newswire; 2012. published 17 August 17.

3. Federoff NV, Battisti DS, Beachy RN, Cooper PJM, Fischhoff DA, Hodges CN, Knauf VC, Lobell D, Mazur BJ, Molden D, Reynolds MP, Ronald PC, Rosegrant MW, Sanchez PA, Vonshak A, Zhu J-K: Radically rethinking agriculture for the $21^{\text {st }}$ century. Science $2010,327: 833-834$.

4. Carpenter J: GM crops and patterns of pesticide use. Science 2001, 292:637-638.

5. Brookes G, Barefoot P: Global impact of biotech crops environmental effects, 1996-2010. GM Crops and Food: Biotech in Ag and the Food Chain 2012, 3:1-9.

6. Sankula S: Quantification of the impacts on US agriculture of biotechnologyderived crops planted in 2005, National Center for Food and Agricultural Policy, 1-110. 2006 [http://www.ncfap.org/documents/ 2005biotechExecSummary]. 
7. Economic Research Service: Genetically engineered crops: has adoption reduced pesticide use?. 2000 [http://webarchives.cdlib.org/sw1610ws5g/http:/ ers.usda.gov/publications/agoutlook/aug2000/ao273f.pdf]

8. USDA National Agricultural Statistics Service: Agricultural Chemical Usage Field Crop Summary, 2003-2005; [http://usda.mannlib.cornell.edu/MannUsda/ viewDocumentInfo.do?document $\mathrm{DD}=1560]$

9. United Kingdom Health and Safety Executive, Expert Committee on Pesticide Residues in Food (PRiF), Pesticide Residues Committee: Pesticide residues monitoring report; third quarter report 2010, quarter ended September 2010.: ; Published 10 March 2010. [http://www.pesticides.gov.uk/Resources/ CRD/igrated-Resources/Documetns/Other/2010_Q3_Report.pdf]

10. Mortensen DA, Egan JT, Maxwell BD, Ryan MR, Smith RG: Navigating a critical juncture for sustainable weed management. BioScience 2012, 62:75-84.

11. Owen MDK: Weed species shifts in glyphosate-resistant crops. Pest Manag Sci 2008, 64:377-387.

12. Duke SO: Comparing conventional and biotechnology-based pest management. J Agric Food Chem 2011, 59:5793-5798.

13. Steffey K, Gray M: IPM and the integrated control concept: progress after 50 years in the commercial corn and soybean landscape? Bulletin. University of Illinois Extension, 2009, No. 1, Article 5.

14. Harker KN, O'Donovan JT, Blackshaw RE, Beckie HJ, Mallory-Smith C, Maxwell BD: Our view. Weed Sci 2012, 60:143-144.

15. Hartzler B, et al: Preserving the value of glyphosate. lowa State University:" 2004. http://www.weeds.iastate.edu/mgmt/2004/preserving.shtml

16. National Agricultural Statistics Service: Agricultural Chemical Usage Field Crop Summary, 1997. [http://usda.mannlib.cornell.edu/MannUsda/ viewDocumentInfo.do?documentID=1560]

17. National Agricultural Statistics Service: Agricultural Chemical Usage Field Crop Summary, 2003. [http://usda.mannlib.cornell.edu/MannUsda/ viewDocumentInfo.do?documentID=1560]

18. National Agricultural Statistics Service: Agricultural Chemical Usage Field Crop Summary, 2007. [http://usda.mannlib.cornell.edu/MannUsda/ viewDocumentInfo.do?documentID=1560]

19. Weed Science Society of America: International survey of herbicide resistant weeds. 2012 [http://www.weedscience.org//n.asp]

20. Padgett SR, Kolacz KH, Delanney X, Re DB: Development, identification, and characterization of a glyphosate-tolerant soybean line. Crop Sci 1995, 35:1451-1461.

21. Bradshaw LD, Padgette SR, Kimball SL, Wells BH: Perspectives on glyphosate resistance. Weed Tech 1997, 11:189-198.

22. Gressel J: Fewer constraints than proclaimed to the evolution of glyphosate-resistant weeds. Resis Pest Manag 1996, 8:2-5.

23. Heap IM: The occurrence of herbicide-resistant weeds worldwide. Pestic Sci 1999, 51:235-243.

24. Benbrook C, Groth E, Hansen M, Halloran J, Benbrook K: Pest Management at the Crossroads. Yonkers, New York: Consumers Union; 1996.

25. Blewett TC: Comments on behalf of Dow AgroSciences LLC on Supplemental information for petition for determination of nonregulated status for herbicide resistant DAS-40278-9 Corn. Economic and agronomic impacts of the introduction of DAS-40278-9 corn on glyphosate resistant weeds in the U.S. cropping system; 2011:1-202.

26. Gaines TA, Zhang W, Wang D, Bukun B, Chrisholm ST, Shaner DL, Nissen SJ, Patzoldt WL, Tranel PJ, Culpepper AS, Grey TL, Webster TM, Vencill WK, Sammons RD, Jiang J, Preston C, Leach JE, Westra P: Gene amplification confers glyphosate resistance in amaranthus palmeri. Proc Nat Acad Sci 2010, 107:1029-1034

27. Gary VF, Harkins ME, Erickson LL, Long-Simpson LK, Holland SE, Burroughs $B L$ : Birth defects, season of conception, and sex of children born to pesticide applicators living in the red river valley of Minnesota, USA. Environ Health Perspect 2002, 110:441-449.

28. Arbuckle TE, Lin ZQ, Mery LS: An exploratory analysis of the effect of pesticide exposure on the risk of spontaneous abortion in an Ontario farm population. Environ Health Perspect 2001, 109:851-857.

29. Schreinemachers DM: Birth malformations and other adverse perinata outcomes in four U.S. Wheat-producing states. Environ Health Perspect 2003, 111(9):1259-1264. July.

30. Rohr JR, McCoy KA: A qualitative meta-analysis reveals consistent effects of Atrazine on freshwater fish and amphibians. Environ Health Perspect 2009, 118(1):20-32. 2010 January.

31. Bernards ML, Crespo R, Kruger GR, Gaussoin R, Tranel PJ: A waterhemp (Amaranthus tuberculatus) population resistant to 2,4-D. Weed Sci 2012, 60:379-384.
32. Owen MDK: Weed resistance development and management in herbicide-tolerant crops: experiences from the USA. Furverbraucherschultz und lebensmittelsicherheit 2011, 6(Suppl 1):85-89.

33. Benbrook CM: The magnitude and impacts of the biotech and organic seed price premium, The Organic Center. 2009. http://www.organic-center.org/ reportfiles/SeedPricesReport.pdf.

34. Chang F-C, Simcik MF, Capel PD: Occurrence and fate of the herbicide glyphosate and its degradate aminomethylphosphonic acid in the atmosphere. Environ Tox and Chem 2011, 30:548-555. doi:10:1002/35c.431.

35. Association of American Pest Control Officials (AAPCO): 2005 AAPCO pesticide drift enforcement survey. 2005. http://aapco.org/documents/surveys/ DriftEnforce05Rpt.html.

36. Kremer RJ, Means NE: Glyphosate and glyphosate-resistant crop interactions with rhizosphere microorganisms. Europ J Agronomy 2009, 31:153-161. doi:10.1016/j.eja.2009.06.004.

37. Fernandez MR, Zentner RP, Basnyat P, Gehl D, Selles F, Huber D: Glyphosate associations with cereal diseases caused by Fusarium spp. in the Canadian Prairies. Europ. Agronomy. 2009, 31:133-143. doi:10.1016/j.eja.2009.07.003.

38. Cakmak I, Yazici A, Tutus Y, Ozturk L: Glyphosate reduced seed and leaf concentrations of calcium, manganese, magnesium, and iron in nonglyphosate resistant soybean. Europ J Agronomy 2009, 31:114-199. doi:10:1016/j.eja.2009.07.001.

39. Zobiole LHS, de Oliveira RS, Huber DM, Constantin J, de Castro C, de Oliveira FA, de Oliveira A: Glyphosate reduces shoot concentrations of mineral nutrients in glyphosate-resistant soybeans. Plant Soil 2009, 328:57-69. doi:10.1007/s11104-009-0081-3.

40. Pleasants JM, Oberhauser KS: Milkweed loss in agricultural fields because of herbicide use: effects on the monarch butterfly population. Insect Conservation and Diversity 2012, doi:10.1111/j.1752-4598-2012.00196.x.

41. Casabé N, Piola L, Fuchs J, Oneto ML, Pamparato L, Basack S, Gimenez R, Massaro R, Papa JC, Kesten E: Ecotoxicological assessment of the effects of glyphosate and chlorpyrifos in an Argentine soya field. J Soils Sediments 2007, 7:232-239. doi:10.1065/jss2007.04.224.

42. Zobiole LHS, de Oliveira R, Kremer RJ, Constantin J, Bonato CM, Muniz AS: Water use efficiency and photosynthesis of glyphosate-resistant soybean as affected by glyphosate. Pesticide Biochem and Physiol 2010, 97:182-193.

43. Zobiole LHS, de Oliveira RS, Kremer RJ, Constantin J, Yamada T, Castro C, de Oliveira FA, de Oliveira A: Effect of glyphosate on symbiotic $\mathrm{N}_{2}$ fixation and nickel concentration in glyphosate-resistant soybeans. App/ Soil EcO 2010, 44:176-180.

44. King AC, Purcell LC, Vories ED: Plant growth and nitrogenise activity of glyphosate-tolerant soybean in response to glyphosate applications. Agron J 2001, 93:179-186.

45. Warwick SI, Légeré A, Simard MJ, James T: Do escaped transgenes persist in nature? The case of an herbicide resistance transgene in a weedy Brassica rapa population. Mol Biol 2007, 17:1387-1395. doi:10.1111/j.1365294X.2007.03567.x.

46. Nguyen HR, Jehle JA: Expression of cry3Bb1 in transgenic corn MON88017. J Agric Food Chem 2009, 57:9990-9996.

47. Stotzky G: Persistence and biological activity in soil of inserted proteins from $B t$ and of bacterial DNA bound on clay and humic acids. J Environ Qual 2000, 29:691.

48. Gray ME: Relevance of traditional Integrated Pest Management (IPM) strategies for commercial corn producers in a transgenic agroecosystem: a bygone era? J Agric Food Chem 2011, 59:5852-5858.

49. Gray ME: Additional reports of severe rootworm damage to Bt corn received: questions and answers, The Bulletin University of Illinois Extension; 2011. No. 22, Article 2

50. Pierce CMF, Gray ME: Population dynamics of a Western corn rootworm (Coleoptera: Chrysomelidea) variant in east central Illinois commercial maize and soybean fields. J Econ Entomol 2007, 100(4):1104-1115. Aug.

doi:10.1186/2190-4715-24-24

Cite this article as: Benbrook: Impacts of genetically engineered crops on pesticide use in the U.S. - the first sixteen years. Environmental Sciences Europe 2012 24:24 